\title{
In Memoriam to William W. Cooper
}

\author{
C. A. Knox Lovell • Robin C. Sickles
}

Published online: 17 November 2012

(c) Springer Science+Business Media New York 2012

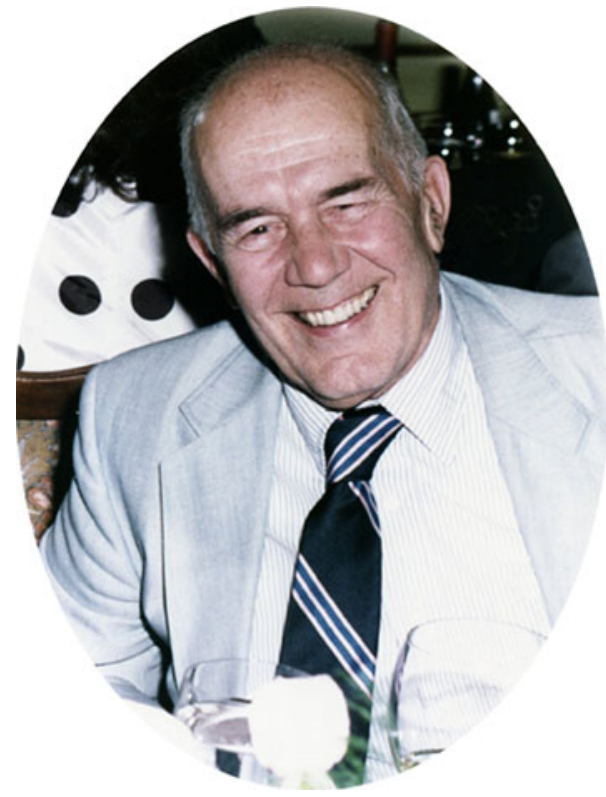

William Wager Cooper passed away June 20, 2012, at the age of 97 . He enriched the lives of all he met, and we are unlikely to see the likes of him again.

Bill's professional accomplishments are not just numerous, they have been significant, and the ensuing honors and accolades are richly deserved and by now well

\section{A. K. Lovell}

CEPA, School of Economics, University of Queensland,

Brisbane, QLD 4072, Australia

e-mail: k.lovell@uq.edu.au

R. C. Sickles ( $\square)$

Department of Economics, Rice University,

Houston, TX 77005, USA

e-mail: rsickles@rice.edu known. A fine tribute is available at http://www.utexas.edu/ know/2012/06/20/cooper-william/. However even this site overlooks an achievement that will be of interest to readers of the Journal of Productivity Analysis who think of Bill as a creator of Data Envelopment Analysis: Bill was publishing papers in Journal of Political Economy, American Economic Review, Accounting Review, Quarterly Journal of Economics and Econometrica long before the creation of DEA, and even before most readers of the Journal were born.

One professional service Bill enthusiastically provided over many years, which has not yet been acknowledged in the many tributes, is his long involvement with the Journal of Productivity Analysis. In this tribute we rectify that oversight.

Ali Dogramaci hosted the Conference on Current Issues in Productivity at Rutgers University in the 1980s. Bill Cooper was there, beginning in 1981, when he was a mere 67. During the later meetings Ali convened several informal gatherings aimed at starting a journal devoted to productivity analysis. Bill was there, providing encouragement and advice. The meetings were fruitful, and Volume 1, Number 1 of the Journal of Productivity Analysis appeared in April 1989, with Ali Dogramaci as Editor-in-Chief and William W. Cooper a member of the Advisory Board. When Lovell succeeded Dogramaci as Editor-in-Chief in 1992, William W. Cooper remained on the Advisory Board. When Sickles succeeded Lovell in 2003, William W. Cooper remained on the Editorial Board. Bill remained there until his passing. Bill offered advice, solicited and unsolicited, and his advice was shaped by over a half century of experience in and beyond academe.

Bill contributed many papers to the Journal of Productivity Analysis. Both of us were fortunate to also contribute to the Special Issue of the Journal of Productivity 
Analysis in Honor of W. W. Cooper in 2002. Bill's last contribution to the Journal of Productivity Analysis was the Symposium of Plenary Presentations from the 2010 North American Productivity Workshop, a workshop interestingly dedicated to another giant in the field of productivity, John W. Kendrick. It was published in the Journal of Productivity Analysis in 2011. Although Bill was unable to attend the conference physically he did attend virtually, as we were able to coordinate a streamed video of him addressing the entire conference. The plenary session was "History
Lessons" in productivity research. Knox Lovell was the other presenter in that plenary session and co-authored the paper in the symposium with Bill. The conference participants, many with their jaws open and tears in their eyes, saw the legend, W. W. Cooper, many for the last time. They saw his sharp mind, his clear message, and his wonderful smile.

We have lost a scholar of colossal proportions, a sagacious advisor, a valued colleague and mentor and, best of all, a friend. 